\title{
The Auction of Shenxin Textile Mill No.7 Plus a Discussion of Shenxin Improvement Committee
}

\author{
Zhengkun $\operatorname{Sun}^{1} \&$ Xiaoming Yang ${ }^{1}$ \\ ${ }^{1}$ College of humanities, Donghua University. Shanghai, China \\ Correspondence: Xiaoming Yang, College of humanities, Donghua University, Songjiang, Shanghai, 201620, \\ China. E-mail: ynide@sina.com
}

Received: December 4, 2019

Accepted: December 11, 2019

Online Published: December 31, 2019

doi:10.5539/ass.v16n1p91

URL: https://doi.org/10.5539/ass.v16n1p91

\begin{abstract}
The auction of Shenxin No.7 had great influence at that time, because it made the Kuomintang government start a series of investigations into Shenxin as a whole. In order to address the plight of the 1930s, Shenxin Improvement Commission was established. On the basis of historical data, the author explores these two issues, and concludes that the unity of the people played a great role in the social injustice at that time, and Shenxin Improvement Committee also played a certain role in addressing the dilemma at that time.
\end{abstract}

Keywords: Shenxin Textile Mill No.7, Shenxin Improvement Committee, HSBC, auction, Rong's family

HSBC illegally auctioned Shenxin No. 7 on the grounds that Shenxin No. 7 failed to repay its debts. Although this auction did not become a reality like the supervision of the bank consortium, it had a certain impact on Shenxin's development and managers' experience during that period. Meanwhile, the Rong family set up the Shenxin Improvement Committee, aiming to improve the operation, production and management of Shenxin Textile system, which indeed improved the operating state of Shenxin system to some extent.

In the early 1930s, the market of spinning business was not good, and Shenxin had to change its way of borrowing money due to its huge debts, damaged commercial credit, and speculation failure: borrowing money by mortgaging fixed assets and liquid assets of each mill respectively. At first, banks only supervised Shenxin mill No.1 and No. 8, then the loan banks and Shenxin formed the Shenxin bank consortium, including 2 representatives from the Bank of China, 1 from the Bank of Shanghai, 2 from the consortium office and 8 from Shenxin including Rong Weiren, Rong Erren and Rong Hongren. Unlike the original supervision of Shenxin mills only, the bank consortium further mastered part of the management rights of the enterprise, and carried out substantial management of part of Shenxin's textile mills for six months. Later, as the loan from the bank was due and Shenxin did not have enough funds to operate, the bank consortium provided loans again and operated and managed Shenxin mill No.1 and No. 8. In fact, the bank consortium also agreed to provide loans to Shenxin No.2 and No.5, but Shenxin did not allow the consortium to manage the enterprises, and the contract was not reached. In October 1936, more restrictive contracts were signed for Shenxin mills No.1, No.2, No.5 and No.8, and the loans were not paid up by Shenxin until 1942.

Under this background, HSBC illegally auctioned Shenxin No. 7 on the grounds that Shenxin No.7 failed to repay its debts. Although this auction did not become a reality like the bank consortium's supervision, it had a certain impact on Shenxin's development and managers' experience during that period.

\section{Analysis of the Cause of "Shenxin No.7 Auction"}

In the early 1930 s, Shenxin textile industry system encountered unprecedented dilemmas. In addition to several companies being supervised by bank consortium, there were also other difficulties, among which, the auction of Shenxin No.7 was one of the difficulties having very serious impact.

The following table (Table 1) is the direct cause and the root cause of the auction of Shenxin No.7:

\begin{tabular}{ll}
\hline Direct Cause & Root Cause \\
\hline Shenxin borrowed two million yuan from HSBC, & There are four root reasons for this event and the \\
which was due in 1934. Shenxin was then unable to & difficulties of Shenxin textile system in that period. \\
repay the loan and asked for a rollover by paying back & First, the Rong family suffered serious losses due to \\
\hline
\end{tabular}


all the interests and part of arrears, but HSBC disagreed and put up for auction. the failure of overseas speculation, so that Shenxin had to use its fixed assets and liquid assets as collateral. Second, what was worse, according to the analysis of bank consortium's control, Shenxin mills' management state was not good at that time, and on the verge of bankruptcy. As a result of the above and various reasons, the creditors worried about Shenxin's ability of continuing the operation, and that's why HSBC came up with the plan to auction off Shenxin No.7. Third, although the Kuomintang government and the Shanghai government proposed to negotiate with HSBC, the bank was not buying it and went its own way. Later, the bank accepted a series of mediation by the Kuomintang government due to great social pressure. Fourth, the instigation of Japanese textile mill is also an important factor.

Through the above analysis, the author believes that the reason for the Shenxin auction event was far more than HSBC's eagerness to recover the arrears. HSBC was indeed desperate to get its capital back, but the operating state of Shenxin system at that time was indeed dismal, which made HSBC lose confidence in the repayment ability of Shenxin No.7. There is also a depreciation rate for equipment and plant. Besides, viewing this as an opportunity to weaken the Chinese textile mills, the Japanese textile mill TOYOTA BOSHOKU instigated HSBC to carry out the auction, so as to weaken the influence of Shenxin. All these events have intensified HSBC's eagerness to sell Shenxin No.7.

In a word, the author believes that the core reason why Shenxin encountered the downturn in the early 1930s lies in: 1, from 1930 to 1933, Shenxin company suffered huge losses due to the failure of overseas speculation, and the huge interest incurred by the speculation was also a great economic pressure, leading Shenxin company to use the fixed assets and liquid materials of each factory as collateral. This is the most critical and direct factor causing the problems of "consortium control" and the "auction of Shenxin No.7". At the same time, a number of other factors interacted to make it difficult for Shenxin to operate during this period.

\section{Pros and Cons of the Failure of Shenxin No.7 Auction}

The failure of Shenxin No.7 auction is mainly because it went against popular sentiments, that is, it greatly violated the interests of the Rong family, and damaged the interests of factory workers. In fact, in the Annual Work Report of Shenxin Improvement Committee, Rong Weiren thought that it's not a bad thing if Shenxin No.7 could sell for a good price, and the Rong family also had the intention to sell mill No.7 after the auction. The auction failed because HSBC auctioned the mill off too cheaply and the spinning mill would later be used for other purpose. The auction of Shenxin No.7 was a complicated issue, and HSBC, Shenxin and other parties hold different attitudes. Through the different attitudes of all parties toward this event, the author analyzes the good and bad influence of the failed auction of Shenxin No.7 on Shenxin and all aspects of the society.

The attitude of each auction party: 1, HSBC: in its opinion, according to the provisions of the original contract, if Shenxin cannot repay the debt at maturity, it has the right to possess and dispose of the property without going through legal procedures. 2, Lawyer of Shenxin and the court of the Republic of China: they thought the contract signed between Shenxin No.7 and HSBC was "Fluidity" contract and was too simple, where HSBC took advantage of Shenxin No.7's difficulties to encroach on Shenxin No. 7's interests. According to the principles of the Republic of China law and international law, it was illegal for HSBC bank not to apply to the court for the auction of Shenxin No.7. 3, Factory workers: workers sent representatives to negotiate with Shanghai municipal government about the auction of Shenxin No.7. Meanwhile, they contacted newspaper offices, public groups and other organizations, to request the power of public opinion, and ask the society to uphold justice. These funds were also raised by workers themselves. Workers of Shenxin No.7 united together and stayed with Shenxin No.7. 4, Banks in Shanghai: the "Central Bank" intended to issue bonds of 3 million yuan to redeem Shenxin No. 7 and then transferred it to the ruling committee of the cotton industry. The bank of Shanghai made two plans, and the core difference is whether Shenxin is a debtor or Shenxin is not allowed to participate in so as to nationalize the factory. Its plan report showed that the parties wanted to achieve the plan where Shenxin is a debtor. 5, Kuomintang government: the Shanghai government and the Kuomintang government had been mediating the 
issue. HSBC ignored it initially, and then stopped the auction of Shenxin No.7 under the pressure. 6, Social organizations: The Chinese Manufacturers' Association issued a letter asking Chinese merchants to break off business with foreign banks, and the Union of Chinese Cotton Mill urged the Kuomintang cotton council to discuss solutions. 7, Buyer: the buyer was Dairen Kisen Kaisha, a Japanese company, and the mill was bought by Toyota textile mill, on behalf of Dairen Kisen Kaisha. Dairen Kisen Kaisha intended to change the mill into a wharf instead of running textile business.

Finally, due to the efforts of all sides and the pressure from the public opinion and other aspects, HSBC bank terminated the auction of Shenxin No.7. The Kuomintang government was also forced to order the ministry of industry to negotiate with HSBC, and the repayment date was extended to December 1936 and the end of 1940 and the annual interest rate was also reduced from 0.8 percent to 0.7 percent. After 1936, the environment of national textile industry was getting better, and HSBC's debt was paid off.

We can learn from HSBC's illegal auction of Shenxin No.7 that, although the court deemed that HSBC had acted illegally, foreign banks did not attach much importance to the laws of the Republic of China at that time. What's more, according to the initial attitudes of the "central bank" and the Kuomintang government, they were also contemptuous of the opinions and suggestions of the government. Therefore, the author believes that the core force preventing the auction of Shenxin No. 7 was the workers of Shenxin No. 7, who communicated with the government and social organizations, to gain social attention and create influence of public opinion, forcing HSBC to abandon the auction of Shenxin No.7. In a word, HSBC's failure to sell Shenxin No.7 was beneficial to the future development of Shenxin No.7 and Chinese enterprises, the legal feasibility of the Republic of China, the stability of national politics, and even to HSBC bank. Firstly, for the future development of Shenxin No.7 and Chinese enterprises: 1, HSBC's illegal low-price auction of Shenxin No.7 was a huge loss to Shenxin No.7: if HSBC directly auctioned Shenxin No.7, the loss to Shenxin No.7 was very large. The value of Shenxin No.7 itself was more than 5 million yuan, but the auction price was 2.25 million yuan, which was only enough to repay the amount of shenxin's mortgage. 2, if the illegal auction of the textile mill was succeeded, other banks would certainly follow suit, so that the development of China's national industry and commerce would encounter a more severe crisis in the long run. Secondly, for the legal feasibility of the government of the Republic of China and the stability of society: 1, the Japanese company, buyer of Shenxin No.7, intended to rebuild the mill into a shipyard, rather than continuing to develop the textile mill, which would cause large-scale unemployment of Shenxin No.7. If other banks follow the example of HSBC and cause widespread unemployment, it would have a negative impact on social stability. 2, HSBC's auction of Shenxin No.7 was an illegal act. If this illegal act was not stopped, foreign enterprises in China would make further and more serious behavior, damaging the interests of the Chinese people. Finally, for HSBC: 1, if Shenxin No.7 was auctioned successfully, it would cause the panic of all Chinese textile mills to foreign banks, which would have a certain impact on the lending of foreign banks, and the impact may be very long. What's more, this event could easily give rise to an anti-imperialist patriotic movement, damaging the overall interests of foreign capitalism and generating panic in China. 2, we can see from this event that the Western bank, when finding the unstable operation state of the Chinese textile mill at that time, totally ignored the safety of national capitalism and sold the mill to a Japanese company. Western enterprises ignored the laws of the Republic of China and the interests of the Chinese people, to buy and sell national capital property at a low price, which was enough to show the sinister intentions of the Western powers and the rampant economic invasion of China at that time.

\section{Role of Shenxin Improvement Committee}

During that period, the Rong family indeed thought a lot about the reform of Shenxin enterprise, such as asking for support of the Kuomintang government, bank lending and borrowing from Fuxin and Maoxin. At the same time, the Rong family established Shenxin Reform Committee to carry out a series of reforms within Shenxin textile system.

According to Rong Weiren, the establishment objective of Shenxin Reform Committee was: positively, it will strive to make some improvements in operation, production and management to make profits and pay off debts more quickly, and on the other hand, it will sell off fixed assets at a best price, such as the Yunzaobang real estate of Shenxin No.7, to pay off debts. Passively, it will maintain the status quo and wait for the market to warm up. Shenxin Improvement Commission has three divisions: the general affairs, business, and factory affairs. The chairman of the improvement committee was Rong Weiren, committee members of each division were key staff of head office and directors of each factories. Besides, each division was also divided into several units, as shown in Figure 1. The division of business was mainly to sort out and reform the accounting system, sales mode, debt and other financial issues of Shenxin textile system. The division of general affairs was mainly responsible for personnel and material, such as the investigation of enterprise personnel, the cutting of redundant personnel, 
the attendance rate of work, and the storage of materials. As the name implies, the division of factory affairs was mainly to manage the cotton of each mill, advantages and disadvantages of its cotton yarn and cloth production, production efficiency, the research and development of the prime mover equipment and other parts of front-line production.

\section{Conclusions}

Through the above analysis, the author believes that, although both the Kuomintang government and Shenxin textile company have made efforts to stop the auction of "Shenxin No.7", they didn't have a really strong effect. Finally, it was the employees of Shenxin No. 7, by uniting together and, appealing for help, that forced HSBC to terminate the auction. The incident also indirectly proved the effect of the unity of the people on the social injustice at that time, and that the weak state of the laws and officials of the Kuomintang government could not effectively protect the people, so that the problem could only be solved by the public and the public opinion.

The author views that the reform plan of Shenxin committee still had some effects. First, the Lenong Annual Chronicle mentioned that "except for the mill No.2, all mills in Shanghai are in good operation. Profits are generated every day, products are white and good, and the inventory is reducing. The longest night is coming to an end", indicating that the reform of the reform committee had achieved some results, and the operation, production and output have been improved. Besides, the Chinese economy as a whole was not booming in 1935, according to the Annual Meeting Report of the Union of Chinese Cotton Mill, "the twenty-fourth year of the Republic of China was one of the most dramatic years of economic changes in our country, and all industries were shaken to the utmost. It is obvious that the cotton textile industry has suffered the largest impact." In such a harsh environment, it was not easy to make improvements. What's more, the total loss of Shenxin head office plus its mills was about 2797521.72 yuan in 1934 and about 2037,000 yuan in 1935. It gained some relief in the state of national economic downturn, which also proved the effectiveness of its reforms.

\section{References}

Chen, L. L. (2011). Shenxin Enterprise's Financial Crisis in 1930s and Its Response. East China Normal University.

Chen, W. Y., Hang, H. M., \& Hu, S. S. (2004). Compilation of Lenong Historical Documents: Rong Desheng and Enterprise Management (pp. 501-505). Shanghai Classics Publishing House.

Huang, H. M. (1982). On the Talent Training of the Rong Family Enterprise. Shanghai Journal of Economics, (2).

Institute of Economics, Shanghai Academy of Social Sciences. (1980). Historical Data of the Rong Family Industrial Enterprise (Vol. 1, pp. 468-470). Shanghai People's Publishing House.

Institute of Economics, Shanghai Academy of Social Sciences. (1980). Historical Documents of the Rong Family Industrial Enterprise (Vol. 1, p. 398). Shanghai People's Publishing House.

Ji, F. (1985). The Auction of Shenxin No.7 in the 1930s, an Event that Shocked the Whole Country. Shanghai Finance, (3), 43-44.

Rong, D. S. (2001). Lenong Annual Chronicle. Shanghai Classics Publishing House.

Xu, F. H. (2011). Foreign-related Disputes and Survival Strategies of National Enterprises-a Case Study of the Auction of Shanghai Shenxin No.7. Historical Review, (3), 123-131, 190.

Xu, F. H. (2011). The Interests Dispute among Enterprises, Governments and Banks-with 1935's Auction of Shenxin No.7 of the Rong Family as the Core. Historical Research, (6), 53-69, 191.

Xu, F. H. (2011). The Interests Dispute among Enterprises, Governments and Banks-with 1935's Auction of Shenxin No.7 of the Rong Family as the Core. Historical Research, (6), 53-69, 191.

Zong, J. R., \& Chen, L. R. (2003). The First Family of Chinese National Industry. World Chinese Press.

\section{Copyrights}

Copyright for this article is retained by the author(s), with first publication rights granted to the journal.

This is an open-access article distributed under the terms and conditions of the Creative Commons Attribution license (http://creativecommons.org/licenses/by/4.0/) 